\title{
Public perceptions of climate change impact on Scottish private water resources
}

\author{
S. N. Egyir, C. Brown \& S. Arthur \\ School of Energy, Geoscience, Infrastructure and Society, \\ Heriot-Watt University, UK
}

\begin{abstract}
Climate change is expected to alter precipitation patterns in the UK despite the perception that it rains a lot and there are abundant water resources in Scotland. These water resources are under immense pressure and there is the need to adapt to water-related changes by ensuring reliable water supply to households whilst protecting the natural environment. This study was aimed to explore the feasibility of a water neutral development in some selected Private Water Supply (PWS) users in Scotland by understanding people's perceptions on climate change and its perceived effects on their source of water supply. Questionnaires were administered randomly to households in three local authorities (Aberdeenshire, the Scottish Borders and the Highlands) who had the highest users of PWS to address the research aims; awareness of climate change and its perceived effects on PWS source and the attitude towards climate change actions for a water neutral development concept. The expectant response rate was targeted at $20 \%$ for all three study areas. The response rate for the Highlands, the Scottish Borders and Aberdeenshire were 27\%, 26\% and 19\% respectively, with the latter being marginally below target. The majority of participants $(86 \%)$ were aware of climate change, but did not believe climate change was occurring, and if it was, it had been beneficial to them and cannot affect their source of PWS. Most participants $(86 \%)$ related climate change to government and private companies' agenda to develop complex policies, but were willing to reduce its impact if only it will affect their own source of PWS.
\end{abstract}

Keywords: climate change, private water supply, water neutral, public perceptions, water, Scotland. 


\section{Introduction}

\subsection{Background}

In the United Kingdom (UK), approximately forty million pounds $(£ 40,000,000)$ was estimated to be spent in treating and pumping waste water from 1990 to 2013 excluding other drivers of treatment enhancement (DEFRA [1]). An adequate supply of clean drinking water is important to sustain human life but its source can be threatened by the impacts of climate change. It has been supposed by some researchers that climate change impacts will be most immediately felt through direct impacts on water resources with extreme events such as floods, droughts and a decline in the quality of water in the years to come [2-5]. Furthermore, climate change has been predicted to alter rainfall and water catchment hydrological responses across the world (Watts et al. [6]). In the UK, climate change is expected to cause a rise in temperatures, modify the precipitation patterns and cause an increase in frequent and extreme weather events (Ritson et al. [7]).

Even though climate change may have an impact on the UK, the impact in Scotland might be severe and different due to the fact that Scotland has a wide range of climatic, physical, economic and other features that distinguish it from the rest of the UK (UK Climate Change Risk Assessment (CCRA) [8]). The Scottish Government has acknowledged climate change will have an extensive effect on Scotland's economy, its people and its environment and is determined to play its part in tackling climate change (Scottish Government [9]). The government passed a Climate Change (Scotland) Act by the Scottish Parliament in 2009 which was followed by a publication on "Low Carbon Scotland: Meeting our Emissions Reduction Targets 2013-2027 - The Second Report on Proposals and Policies (RPP2)" on 27th June 2013 (Scottish Government [9]). The reports create a framework for reducing greenhouse emissions by $80 \%$ in 2050 and to ensure delivery of this target the Scottish Ministers are to set annual targets, which include public bodies, but not individual bodies. Though the government has made a commitment to dealing with climate change issues and its impacts, there remains a low level of public engagement in tackling climate change and mitigation actions by Scottish inhabitants especially those in rural and peri-urban communities.

Taking everything into account in terms of differences in Scotland's climate, publication from the UK Climate Projections published in 2009 (UKCP09), predicts Scotland to experience increasing average temperatures throughout the year, an increase in average rainfall in winter, a decrease in average rainfall in summer and rising sea levels (CCRA [8]). This can be evidenced in the observational weather data obtained from the Meteorological (Met) office which shows that the climate in Scotland has changed significantly over the last 40 years since 1961 with average temperatures increasing by $0.5^{\circ} \mathrm{C}$ with most of the areas experiencing a significant rise in precipitation. Looking at the Met data, precipitation increase was more pronounced in the winter months with the East of Scotland experiencing a $36.5 \%$ increase and the North and West of Scotland 
receiving an increase of $67 \%$ to $69 \%$ between 1961 and 2004 (Barnett et al. [10]). Adapting to these precipitation changes is a pressing challenge since over the past few years there has been pronounced observation of major flooding and landslides becoming more frequent in some parts of Scotland which has not been compatible for a sustainable development (UK CCRA [8]).

\subsection{Problem statement}

Climate change impacts in urbanized catchments are among the key major discussions in adapting and dealing with the effects on water resources; its quality and quantity in urbanised catchments (Astaraie-Imani et al. [11]) with less focus on adaptations and the effects on water supply (quality and quantity) in peri-urban and rural areas. In Scotland the majority of rural communities use a Private Water Supply (PWS). Despite the common perception that it rains a lot in Scotland, the water resources are under pressure. A high volume of water is taken from the environment for human use which utilizes high amount of energy to transport and treat good quality water for human consumption. There is the need to plan carefully for the future to ensure reliable water supplies are available for everyone whilst protecting the natural environment (EA [12]). Though the potential impacts of climate change have been considered in UK water resources planning for a decade $[13,14]$, nothing has been implemented for Scotland in terms of PWS usage. The CCRA has considered the main opportunities and threats (CCRA [8]), that may result from the impacts of climate change but there is no policy or implementation of policies concerning peri-urban and rural areas. Adaptation plans to mitigate impact of climate on source of water supply for private water users seem scarce and there is the need for future plans and practical adaptation actions to ensure PWS resources in rural communities are safe from the impacts climate change might have on them through contamination and pollution. Global Climate Change (GCC) according to Cunha et al. [15] is a problem and the aftermath effects are likely to be less severe if mitigation and adaptation measures are planned and applied in accordance to local or regional specificities. Hence to create an action plan, there is the need for a framework which bridges the gap between the attitudes, behaviour and perception of people towards climate change and the impact it might have on their water resources to create socio-economic policies and also improve water course quality whiles protecting the natural environment.

\section{Aim}

This study was aimed to explore the perceptions of PWS users in selected periurban areas in Scotland on climate change and its effects on their source of water supply.

\subsection{Specific objectives}

The specific objectives set were to explore if:

1. PWS users were aware of climate change happening; 
2. PWS users perceived climate change to have an impact on their source of private water supply and

3. there was willingness to reduce the impact of climate change.

\section{Method}

A postal questionnaire survey was conducted in three case study areas: Aberdeenshire, the Highlands and the Scottish Borders. These areas were selected because they had the highest users of PWS in Scotland. The questionnaire consisted of 40 questions in 4 sections varying from Likert scale to multiple-choice questions. The questions were divided into 4 sections: water supply and source of PWS (shared or not shared), measures of water consumption, water conservation and climate change. A total of 4 questions were dedicated to demographic characterization of the sample (sex, age, tenancy and type of building).

The Scottish Borders were used as a pilot study to test the response and distribution of the questionnaires. Overall, a total of 1,000 questionnaires were distributed within the areas. The number of questionnaires sent and expected (in brackets) was as follow: Aberdeenshire had the highest PWS users so a total of 400 questionnaires (80); the Scottish Borders the second highest; 250 questionnaires sent (50) and the Highlands which was the third highest was sent 350 questionnaires (70). The questionnaires were posted randomly to the selected case study areas using the list of private water users provided by their council. An additional 34 questionnaires were further added to the 1,000 questionnaires to replace the undelivered which were regarded as void.

\section{Results and discussion}

A total of 235 questionnaires were received and this comprised $26 \%$ and $27 \%$ respectively in the Scottish Borders (65) and the Highlands (96) respectively, exceeding the targeted response rate the response rate from questionnaires received. The response rate for Aberdeenshire (74) was 19\% which was just below the original target of $20 \%$.

\subsection{Water supply and sources of PWS}

It was observed that all participants in the three case study areas were using PWS due to the fact that there was no other water supply in their neighbourhood or it was already there when they moved in (fig. 1). The most common source of PWS detected was the spring in all the three areas (fig. 1) but other alternate sources varied. Examples as seen in the Scottish Borders, borehole and stream were the next wide source of PWS; in the Highlands it was the stream, watercourse and the borehole whiles in Aberdeenshire it was the well (fig. 1).

Most research in UK on climate change and its impact is mostly focused in urban areas due to urban migration and increase in population. There is also a rich and growing academic literature on the future impact of climate change, 
which covers mostly on the aspect of water or the water environment, river flows, droughts, extreme rainfall, floods in the UK but with mostly a focus on England and Wales [6, 16-19]. To date there is none on rural areas and the impact on their source of PWS. From fig. 1, it can be observed that most rural communities in Scotland use PWS because it is the only option to use.

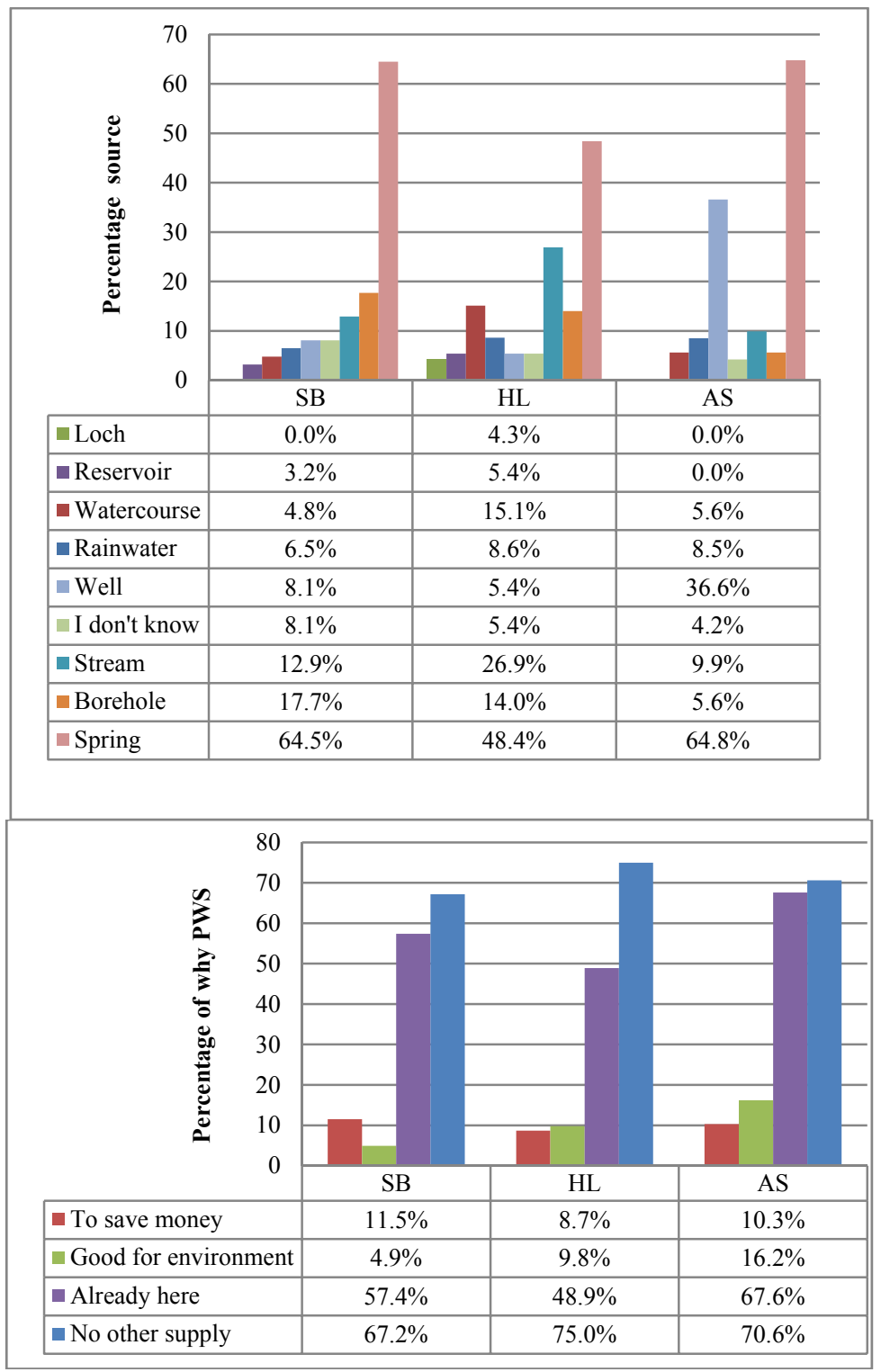

Figure 1: The source and reason for the use of PWS: SB (Scottish Borders); AS (Aberdeenshire); HL (Highland). 
Most research in the UK on climate change and its impact is mostly focused in urban areas due to urban migration and increase in population. There is also a rich and growing academic literature on the future impact of climate change, which covers mostly on the aspect of water or the water environment, river flows, droughts, extreme rainfall, floods in the UK but with mostly a focus on England and Wales [6, 16-19]. To date there is none on rural areas and the impact on their source of PWS. From fig. 1, it can be observed that most rural communities in Scotland use PWS because it is the only option to use.

\subsection{Climate change awareness and impact on source of PWS}

It was observed that most of the participants were aware of climate change: in the Scottish Borders 84.1\%; Aberdeenshire 79.4\% and in the Highlands $88.1 \%$ (fig. 2). It was only in Aberdeenshire that $4.1 \%$ expressed not at all being aware of climate change.

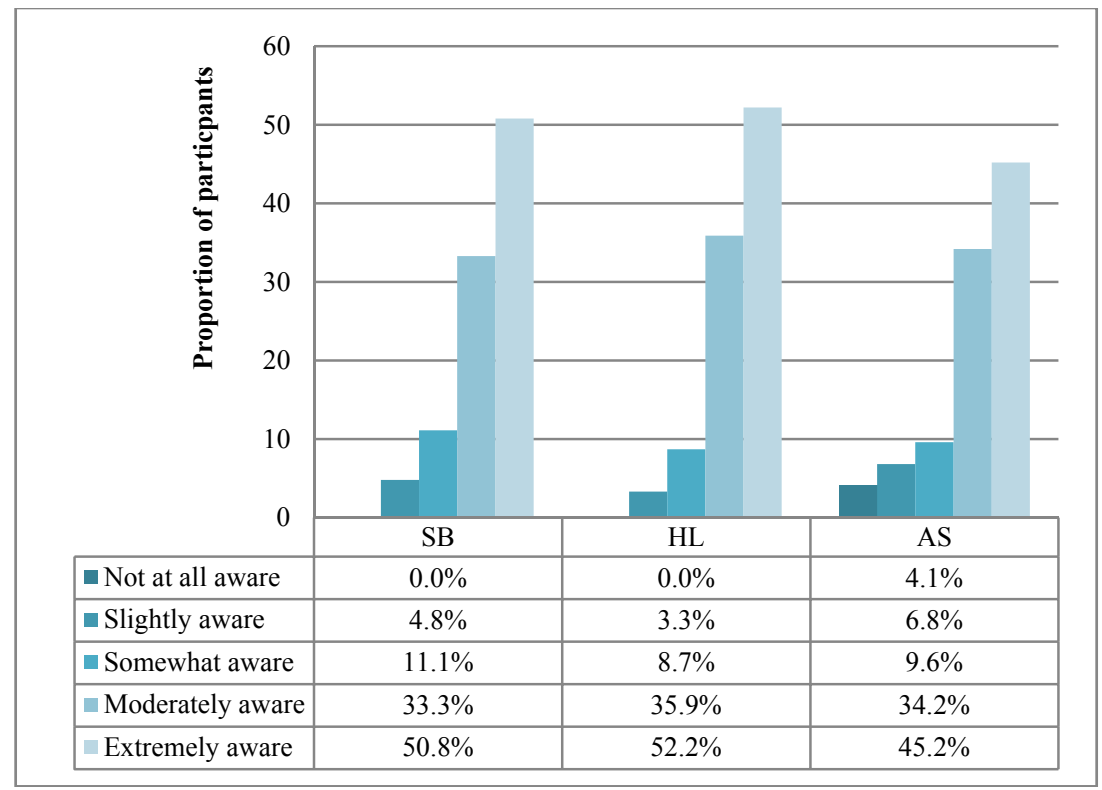

Figure 2: Participants' awareness of climate change.

The awareness of climate change question aimed to test public awareness of climate change in terms of relevant knowledge and concern through the media, friends or community. Though there were a large proportion of participants expressing awareness of climate change (fig. 2), they did not believe it was happening and if it was it has been beneficial to them; this is further observed in their response if climate change would affect their source of PWS where they believed so but in a positive way (fig. 3). The lack of perceived awareness in terms of negative impact of climate change perchance is as a result of the 2008 
Climate Change Act not implementing on public engagement; especially for inhabitants in rural and peri-urban communities on PWS. According to Lockwood [20], the 2008 Climate Change Act is a difficult policy therefore has become a policy problem due to low political salience and immediate cost and has failed to produce political certainty and investor confidence; therefore this

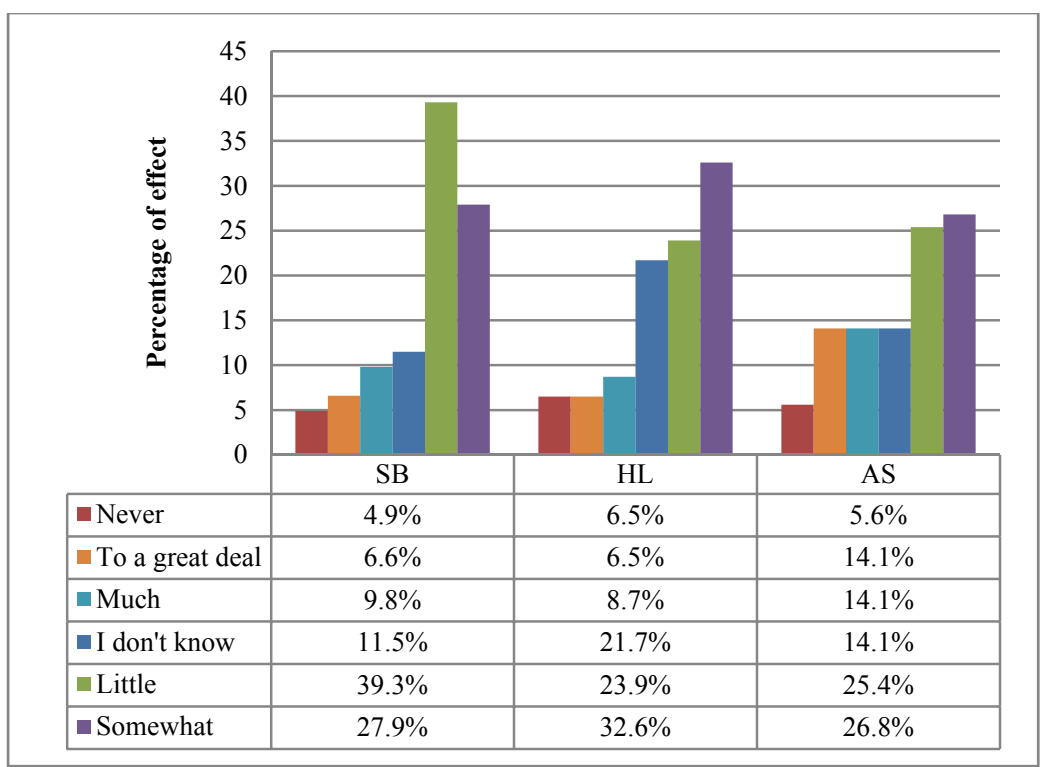

Figure 3: Participants' perception on the effect of climate change on their PWS.

might have resulted in public engagement being in theory more than in implementation.

Participants further expressed diverse opinions on climate change. Some perceived climate change as one of the governments' agenda to frighten them by presenting some facts just to bring in their own "green" agendas. According to Capstick and Pidgeon [20], doubts about climate change exist in the form of scepticism and it is often related to the lack of clarity in previous work as to what exactly "scepticism" comprises. Scepticism has also been known to be associated with low environmental awareness and low risk awareness (Engels et al. [22]). Though participants were aware of climate change, their doubt that it was happening can be attributed to not having enough knowledge on what climate change really is and how they can be affected as suggested by Engel et al. [22]. Furthermore, scepticism among participants was evident because they believed that the climate changes: winter, spring, summer and autumn, therefore they doubted the negative impacts of climate change but believed in the favourable effects of the climate changing in terms of more rainfall, more water for their source of PWS therefore believing climate change affects their source of PWS (fig. 3). This observation of doubt was further more pronounced where most of 
the participants in addition perceived they were aware of climate change but it was not really that serious because they felt if the terminology 'climate change' was taken out of the questionnaire and replaced with: "do you think change in climate change could impact on water resources and supply in Scotland"; the answer to that question they felt should be simple yes in terms of, "if it doesn't rain for a long time there's no water", so to them they doubted the negative impacts of climate and attributed it rather to luck in terms of rain or no rain when the climate changes: winter, spring, summer and autumn.

Gifford et al. [23] and Lorenzoni and Pidgeon [24] state that "climate change is often seen by people as a temporally distant phenomenon primarily affecting other places, times or peoples"; as observed in this study, some participants perceived climate change to be happening but they did not think Scotland will be permanently affected by any reduction in water supply or quality but maybe in the foreseeable future. In fact they believed Scotland has abundant water resources to be affected by climate change and they will rather gain more as they have witnessed increase in rainfall over the years hence there will be no negative impacts on their water resources. To a great deal, participants believed climate change had a $6.6 \%$ (in the Scottish Borders); $6.5 \%$ (in the Highlands) and a $14.1 \%$ (in Aberdeenshire) chance of affecting their source of PWS negatively (fig. 3). This is not surprising as in 2006; research by Lorenzoni and Pidgeon [24] observed that the perceived risk of climate change was seen as a distant threat and of a limited personal importance. Seeing climate change as a distant phenomenon was also evident in this study because comments from participants in all the case study areas perceived climate change to be a lie and even if it will happen it will be a one hundred years from now or when they were dead; others subscribed to the notion that southern England should rather have more concerns for impact on their water resources and a change in climate. Furthermore recent studies have noted declines in the public's acceptance of climate science in terms of the climate changing and the perceived absence of government policies that target combating impacts felt by climate change [2527] therefore, some respondents perceived climate change does not exist as portrayed by the media and even if it was proven beyond doubt nothing will really be done about it.

Participants that perceived climate change was happening were happy because they felt they had benefited from it and this can be seen in fig. 3 were participants felt it had an impact on their source of PWS but in a positive way. A participant made the comment: "our farm has got wetter over the last 40 years; climate change is making our supply more secure". According to Nisbet and Myers [28] the impacts of climate change could be attributed to lower priority than other social and environmental issues and in relation to this study, it was evident in some respondents being more concerned about pollution and diseases for the future. One participant expressed this opinion: "whilst I am worried about climate change globally and locally, the local part (I don't think will have much effect on my water supply - an increase if anything); however, globally there may well be problems with supply, pollution and disease"; attesting to the fact the priority was not necessarily on climate change. 


\subsection{Willingness to reduce the impact of climate change}

Although there were varied perceptions as to whether climate change was real or not and most participants related it to government and private companies' agenda to create complex policies, majority of them were willing to reduce the impact of climate change if it will directly affect their source of PWS: $73.8 \%$ (in the Scottish Borders); 73.9\% (in the Highlands) and 74.3\% (in Aberdeenshire) (fig. 4). Though existing work indicates a distinct difference between individual intentions to engage in mitigation and actual action (Pidgeon et al. [29]), participants in all the study areas showed a relatively low minimal hesitancy in helping to reduce the impact climate change may arise in terms of low water quality, flooding and droughts. According to Sharples [30], there remains a surprising low level of public engagement in tackling climate change although the public are not totally ignorant of the climate change issues but rather falls short in understanding the key aspects (Lorenzoni et al. [31]). The key aspect in this study was a reduction in "water quality", "flooding" and possible effects of "drought" in Scotland perceived to have abundant rainfall which was an enough incentive to make them willing to reduce the impact and be water neutral. Furthermore, in all three areas; the questionnaires somehow created awareness of climate change (which was not intended to).

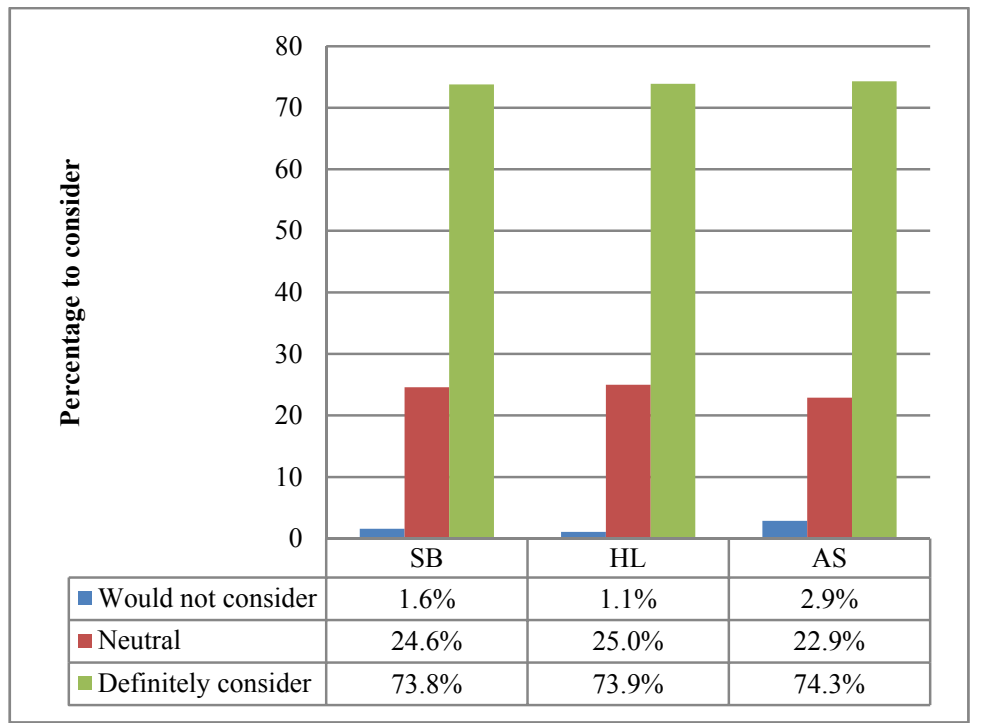

Figure 4: Participants to reduce the impact of climate change if it will affect their source of PWS.

\section{Conclusion}

This study has shed valuable light on the issue of public perceptions of climate change of residents who are not on the mains water supply and in live in rural 
Scotland adding weight to the climate change debate. The general perception that climate change may impact negatively on water resources and people was perceived to be a myth and participants believed climate change to be good. It was observed the "wording of climate change" means the climate is constantly changing and it was a continuous action and not a new thing of which private companies and government institutions were banking on to make profits through complex policies. Therefore it has emphasized the need for public education and engagement of rural and peri-urban communities on the effects of both positive and negative impacts of climate change since participants were willing to reduce the impact of climate change if they will be affected directly. This enforces a need to review existing policies, plans and framework which incorporates public engagement in both theory and practical on climate change action plans to ensure PWS users are safe and prepared to adapt to climate change impact for water neutrality to be feasible. It is recommended that such a policy document or framework should involve an active public engagement.

\section{References}

[1] Department for Environment, Food \& Rural Affairs and Environment Agency (DEFRA), Waste water treatment in the United Kingdom, (2012). Implementation of the European Union Urban Waste Water Treatment Directive - 91/271/EEC. Published by the Department for Environment, Food and Rural Affairs, PB13811.

[2] Rockström, J., Steffen, W., Noone, K., Persson, A., Chapin, F. S., Lambin, E. F., Lenton, T. M., Scheffer, M., Folke, C., Schellnhuber, H. J., Nykvist, B., de Wit, C. A., Hughes, T., van der Leeuw, S., Rodhe, H., Sörlin, S., Snyder, P. K., Costanza, R., Svedin, U., Falkenmark, M., Karlberg, L., Corell, R. W., Fabry, V. J., Hansen, B., Walker, B., Liverman, D., Richardson, K., Crutzen, P. \& Foley, J. A., A safe operating space for humanity, Nature 461:472-475, 2009. Rural water supplies PDF file.

[3] Millennium Ecosystem Assessment (MEA), Ecosystems and human wellbeing: wetlands and water synthesis. World Resources Institute, Washington, D.C., USA, 2005.

[4] Bates, B. C., Kundzewicz, Z. W., Wu, S. \& Palutikof, J. P. Editors, Climate change and water. Technical Paper of the Intergovernmental Panel on Climate Change (IPCC). IPCC Secretariat, Geneva, Switzerland, 2008.

[5] Department for Environment, Food \& Rural Affairs and Environment Agency (DEFRA), Policy: Adapting to climate change, (2013). Page available: https://www.gov.uk/government/policies/adapting-to-climatechange (accessed on 19th October, 2013).

[6] Watts, G., Battarbee, R., Bloomfield, J. P., Crossman, J., Daccache, A., Durance, I., Elliot, J., Garner, G., Hannaford, J., Hannah, D. M., Hess, T., Jackson, C. R., Kay, A. L., Kernan, M., Knox, J., Mackay, J., Monteith, D. T., Ormerod, S., Rance, J., Stuart, M. E., Wade, A. J., Wade, S. D., Weatherhead, K., Whitehead, P. G. \& Wilby, R. L., Climate change and water in the UK - past changes and future prospects, Report Cards, In: 
Progress in Physical Geography. (Progress in Physical Geography, 14 February 2015, 39(1):6-28), 2015.

[7] Ritson, J. P., Graham, N. J. D., Templeton, M. R., Clark, J. M., Gough, R. \& Freeman, C., The impact of climate change on the treatability of dissolved organic matter (DOM) in upland water supplies: A UK perspective. Science of the Total Environment; Mar 1, 2014, 473 pp. 714730, 17p, 2014.

[8] UK Climate Change Risk Assessment (CCRA), Policy: Adapting to climate change in Scotland, 2012. Summary for Scotland pdf files.

[9] Scottish Government, 2015. Climate Change Legislation. Page available: http://www.legislation.gov.uk/asp/2009/12/2009-08-05 (accessed 23rd March, 2015).

[10] Barnett, C., Hassell, J., Perry, M., Procter, C. \& Hughes, G. A., Handbook of Climate Trends Across Scotland. SNIFFER Project CC03, Scotland and Northern Ireland Forum for Environmental Research, Edinburgh, 2006.

[11] Astaraie-Imani, M., Kapelan, Z., Fu, G. \& Butler, D, Assessing the combined effects of urbanisation and climate change on the river water quality in an integrated urban wastewater system in the UK. Elsevier Ltd: In Journal of Environmental Management 2012-12-15 112:1-9, 2012.

[12] Environment Agency (EA), A Scenario Approach to Water Demand Forecasting, National Water Demand Management Centre, Worthing, 2001.

[13] Arnell, N.W. \& Delaney, E.K., Adapting to climate change: Public water supply in England and Wales. Climatic Change 78, 227-255, 2006.

[14] Subak, S., Climate change Adaptation in the U.K. water industry: Managers' perceptions of past variability and future scenarios. Water Resources Management 14, 137-156, 2000.

[15] Cunha, R. T., Rangel, B., Vieira, O. \& Rego, I. E., Is it really happening here? A study of climate change perception in the Azores, WIT Transactions on Ecology and the Environment, Vol 130, pp. 113-120, 2010.

[16] Christensen, J.H., Hewitson, B., Busuioc, A., Chen, X. Gao, A., Held, I., Jones, R., Kolli, R. K., Kwon, W.-T., Laprise, R., Magaña Rueda, V., Mearns, L., Menéndez, C.G., Räisänen,J., Rinke, A., Sarr, A. \& Whetton, P., Regional climate projections. Climate change 2007: The physical science basis. Contribution of Working Group I to the Fourth Assessment Report of the Intergovernmental Panel on Climate Change, Cambridge University Press, Cambridge, UK pp. 847-940, 2007.

[17] Prudhomme, C., Young, A., Watts, G., Haxton, T., Crooks, S., Williamson, J., Davies, H., Dadson, S. \& Allen S., The drying up of Britain? A national estimate of changes in seasonal river flows from 11 Regional Climate Model simulations. Hydrological Processes 26: pp. 1115-1118, 2012.

[18] Blenkinsop, S., \& Fowler, H. J., Changes in drought frequency, severity and duration for the British Isles projected by the PRUDENCE regional climate models. Journal of Hydrology 342: pp. 50-71, 2007. 
[19] Burke, E. J., Perry, R. J. H. \& Brown, S. J., An extreme value analysis of UK drought and projections of change in the future. Journal of Hydrology 388: pp. 131-143, 2010.

[20] Capstick, S. B. \& Pidgeon, N. F., What is climate change scepticism? Examination of the concept using a mixed methods study of the UK public. Global Environmental Change, Volume 24, pp. 389-401, 2014.

[21] Lockwood, M., The political sustainability of climate policy: the case of the UK climate change act. Global Environmental Change Volume 23, Issue 5, pp 1339-1348, 2013.

[22] Engels, A., Hüther, O., Schäfer, M., \& Held, H., Public climate-change skepticism, energy preferences and political participation. Global Environmental Change Volume 23, Issue 5, pp. 1018-1027, 2013.

[23] Gifford, R., L. Scannell, L., Kormos, C., Smolova, L., Biel, A. \& Boncu, $\mathrm{S}$. et al., Temporal pessimism and spatial optimism in environmental assessments: an 18-nation study Journal of Environmental Psychology, pp. 1-12, 2009.

[24] Lorenzoni, I. \& Pidgeon, N.F., Public views on climate change: European and USA perspectives Climatic Change, 77, pp. 73-95, 2006.

[25] Spence, A., Venables, D., Pidgeon, N., Poortinga, W., \& Demski, C., Public Perceptions of Climate Change and Energy Futures in Britain: Summary Findings of a Survey Conducted in January-March 2010. Technical Report (Understanding Risk Working Paper 10-01) Understanding Risk Group, Cardiff University (2010).

[26] Leiserowitz,A., Maibach, E., Roser-Renouf, C., Smith, N. \& Dawson E., Climategate, Public Opinion and the Loss of Trust New Haven, CT (2010). Page available: http://environment.yale.edu/climate/publications/ climategate-public-opinion-and-the-loss-of-trust (accessed on 28th February, 2015).

[27] Pidgeon, N. F., Public understanding of, and attitudes to, climate change: UK and international perspectives and policy. Climate Policy, 12 (S1) (2012), pp. S85-S106, 2012.

[28] Nisbet, M. C. \& Myers, T., Twenty years of public opinion about global warming Public Opinion Quarterly, 71 (3), pp. 1-27, 2007.

[29] Pidgeon, N. F., Lorenzoni, I., \& Poortinga, W., Climate Change or Nuclear Power-No Thanks! A Quantitative Study of Public Perceptions and Risk Framing in Britain, Global Environmental Change, 18(1), pp. 69-85, 2008.

[30] Sharples, D. M., Communicating Climate Science: Evaluating the UK Public's Attitude to Climate Change. Earth and e-nvironment 5, pp. 185205, 2010.

[31] Lorenzoni, I., Nicholson-Cole, S., \& Whitmarsh, L., Barriers Perceived to Engaging with Climate Change among the UK Public and their Policy Implications, Global Environmental Change, 17(3-4), pp. 445-459, 2007. 